\title{
PENINGKATKAN HASIL BELAJAR SISWA DALAM PEMBELAJARAN TEKS FANTASI DENGAN MEDIA RUMAH FANTASI KELAS VIIF TAHUN PELAJARAN 2018/2019 DI SMP NEGERI I SITIUNG
}

\author{
Suratni \\ (Guru SMP Negeri 1 Sitiung) \\ ibusuratmi@544gmail.com
}

\begin{abstract}
This study aims to improve student learning outcomes in Indonesian subjects using fantasy home learning media in class VIIF of SMP Negeri 1 Sitiung. This type of research is Classroom Action Research, with the research subjects being class VIIF students consisting of 30 students. The research data were collected using observations, field notes, learning outcomes test sheets, and documentation in cycles I and II. The data obtained were analyzed using percentage analysis. The results of the research related to learning outcomes, indicate that this fantasy home learning media can improve student learning outcomes, because students have succeeded in achieving the predetermined KKM. This can be proven by increasing students' learning mastery in each cycle, namely cycle I (47\%) and cycle II (93\%).
\end{abstract} Keywords: Learning outcomes, fantasy text, fantasy house

\begin{abstract}
Abstrak
Penelitian ini bertujuan untuk dapat meningkatkan hasil belajar peserta didik pada mata pelajaran bahasa Indonesia dengan menggunakan media pembelajaran rumah fantasi di kelas VIIF SMP Negeri 1 Sitiung. Jenis penelitian ini adalah Penelitian Tindakan Kelas (Classroom Action Research), dengan subjek penelitian adalah peserta didik kelas VIIF yang berjumlah sebanyak 30 orang peserta didik. Data penelitian ini dikumpulkan dengan menggunakan observasi, catatan lapangan, lembar tes hasil belajar, dan dokumentasi pada siklus I dan II. Data yang diperoleh dianalisis menggunakan analisis persentase. Hasil penelitian terkait dengan hasil belajar, menunjukkan bahwa media pembelajaran rumah fantasi ini dapat meningkatkan hasil belajar peserta didik, karena peserta didik sudah berhasil mencapai KKM yang telah ditetapkan. Hal itu dapat dibuktikan dengan peningkatan ketuntasan belajar peserta didik dalam setiap siklus, yaitu siklus I (47\%) dan siklus II (93\%).
\end{abstract}

Kata Kunci : Hasil belajar, teks fantasi, rumah fantasi

\section{PENDAHULUAN}

Pembelajaran Bahasa Indonesia di sekolah bertujuan supaya peserta didik mampu atau terampil berbahasa. Keterampilan berbahasa menyangkut empat aspek yakni terampil menyimak, berbicara, membaca, dan menulis. Keempat aspek tersebut saling berkaitan dan mendukung. Keempat keterampilan tersebut terintegrasi dalam kompetensi dasar pada mata pelajaran Bahasa Indonesia dan diharapkan peserta didik memilikinya. 
Berdasarkan pengalaman penulis di kelas VIIF SMP Negeri I Sitiung peserta didik belum berhasil menguasai Kompetensi Dasar (KD) menelaah unsurunsur dan kebahasaan dari surat pribadi dan surat dinas. Hal tersebut dapat dilihat dari hasil penilaian ulangan harian kedua pada semester dua. Berdasarkan hasil ulangan harian diperoleh dari 30 peserta didik sebanyak 14 orang yang memperoleh hasil di bawah KKM (Kriteria Ketercapaian Minimal) dengan KKM 70. Selain itu, hanya 18 orang mengerjakan tugas dengan baik. Dengan demikian, menandakan bahwa pembelajaran belum berhasil.

Hasil refleksi diperoleh data bahwa selama proses pembelajaran peserta didik banyak yang lesu, tidak semangat, tidak mengerjakan tugas karena malas, dan lain-lain. Hal itu terjadi karena peserta didik sifat hanya mendengarkan saja. Peserta didik cenderung pasif jika hanya dengan model ceramah dan penugasan. Selain masalah hasil belajar yang belum mencapai KKM ada beberapa permasalahan yang muncul pada saat belajar mata pelajaran bahasa Indonesia. Sikap dan perilaku yang tidak baik masih saja dijumpai seperti terlambat masuk kelas, mengerjakan tugas di rumah menjelang belajar, suka ribut, mengganggu teman, mengantuk di kelas saat belajar, dan tidak serius pada saat belajar.

Dari uraian di atas dapat diketahui adanya kesenjangan antara kondisi nyata yang terjadi di kelas dengan kondisi harapan. Hal ini merupakan masalah yang terjadi di dalam kelas, yang mengurangi mutu atau kualitas pembelajaran. Adapun permasalahan-permasalahan yang terjadi mengakibatkan rendahnya hasil belajar peserta didik. Masalah ini harus segera diatasi, proses pembelajaran harus diperbaiki. Salah satu cara untuk mengatasi masalah tersebut adalah dengan memilih model dan media yang tepat. Dengan pemilihan media yang tepat diharapkan dapat mengatasi permasalahan. Salah satu media yang digunakan adalah media visual Rumah Fantasi. Dari latar belakang masalah yang telah dipaparkan, peneliti ingin melakukan perbaikan pembelajaran sehingga sesuai dengan tujuan pembelajaran.

Penilaian hasil belajar dilakukan oleh seorang pendidik mencakup tiga aspek yaitu aspek pengetahuan, keterampilan, dan sikap. Penilaian aspek pengetahuan dilakukan untuk mengetahui tingkat penguasaan kecakapan berpikir peserta didik. Penilaian aspek keterampilan dilakukan untuk mengetahui kemampuan peserta didik menerapkan pengetahuan dalam melaksanakan tugas. Penilaian sikap dilakukan untuk mengetahui tingkat perkembangan sikap spiritual dan sikap sosial peserta didik.

Hasil belajar adalah kemampuan-kemampuan yang dimiliki peserta didik setelah menerima pengalaman belajarnya (Sudjana, 2004:22). Sedangkan menurut Horwart Kingsley dalam bukunya Sudjana membagi tiga macam hasil belajar mengajar : (1). Keterampilan dan kebiasaan, (2). Pengetahuan dan pengarahan, (3). Sikap dan cita-cita (Sudjana, 2004:22).

Menurut Bower (dalam Djamarah, 2006:29), "Belajar berhubungan dengan perubahan tingkah laku seseorang terhadap sesuatu situasi yang disebabkan oleh 
pengalamannya yang berulang-ulang dalam situasi itu, dimana perubahan tingkah laku itu tidak dapat dijelaskan atau dasar kecendrungan respon pembawaan kematangan". Adapun menurut Arikunto (2007:23), "Belajar terjadi apabila situasi stimulus bersama dengan isi ingatan mempengaruhi peserta didik sedemikian rupa sehingga perbuatannya (performance) berubah dari waktu sebelum ia mengalami situasi itu ke waktu sesudah ia mengalami situasi tadi". Sementara, Dimyati dan Mudjiono (2006) mengemukakan "Belajar merupakan suatu proses internal yang kompleks, yang terlibat dalam proses internal tersebut adalah yang meliputi unsur afektif, dalam matra afektif berkaitan dengan sikap, nilai-nilai, interes, apresiasi, dan penyesuaian perasaan sosial."

Dari pendapat di atas dapat disimpulkan bahwa belajar merupakan suatu perubahan dalam tingkah laku, dan perubahan itu terjadi melalui latihan atau pengalaman yang berulang-ulang. Perubahan melalui belajar selalu dilakukan oleh individu sepanjang hidupnya. Perubahan yang terjadi pada individu yang belajar dapat disebut hasil belajar. Dalam Kamus Besar Bahasa Indonesia "hasil belajar diartikan sebagai sebuah penguasaan pengetahuan atau keterampilan yang dikembangkan melalui mata pelajaran, lazimnya ditunjukkan dengan nilai tes atau angka nilai yag diberikan oleh guru". Hasil belajar yang dicapai seseorang merupakan hasil yang diperoleh melalui proses belajar dan dipengaruhi oleh faktor yang bersifat internal atau eksternal. Perubahan yang terjadi biasanya dapat dilihat dengan bertambah baiknya atau meningkatnya kemampuan yang dicapai seseorang.

Media pembelajaran menurut Aqib (2014:100) ialah sarana pembelajaran yang digunakan sebagai perantara dalam proses pembelajaran mempertinggi efektivitas dan efesiensi dalam mencapai tujuan pembelajaran. Media pembelajaran secara umum adalah alat bantu proses belajar mengajar. Segala sesuatu yang dapat dipergunakan untuk merangsang pikiran, perasaan, perhatian, dan atau keterampilan pembelajaran sehingga dapat mendorong proses pembelajaran.

Selanjutnya, menurut Azhar (2011) menyatakan bahwa media pembelajaran adalah alat bantu pada proses belajar baik di dalam maupun diluar kelas, lebih lanjut dijelaskan bahwa media pembelajaran adalah komponen sumber belajar atau wahana fisik yang mengandung materi intruksional di lingkungan siswa yang dapat merangsang siswa untuk belajar. Sementara menurut Schramm (1977) dikutip dalam Rudi dan Cepi (2008: 6) menjelaskan bahwa media pembelajaran adalah teknologi pembawa pesan yang dapat dimanfaatkan untuk keperluan pembelajaran. Kemudian, Romiszowski dalam Basuki dan Farida (2001: 12) media pembelajaran adalah media yang efektif untuk melaksanakan proses pengajaran yang direncanakan dengan baik.

Media pembelajaran rumah fantasi adalah sebuah media yang tergolong visual. Media visual adalah alat atau sarana komunikasi yang dapat dilihat dengan indra penglihatan. Media visual terbagi dua, yaitu visual bergerak dan diam 
(takbergerak). Menurut Wibawa dan Mukti (1992:27) menjelaskan bahwa "Media visual dibedakan menjadi dua yaitu media visual diam dan media visual gerak. Media visual diam antara lain: foto, ilustrasi, flash card, gambar pilihan, potongan gambar, film bingkai, tilm rangkai, tranparasi proyektor, tak tembus pandang, mikrofis, overhead proyektor, stereo proyektor, mikro proyektor, dan tachitoscopes, serta grafis, bagan, diagram, poster, gambar kartun, peta, dan globe sedangkan visual bergerak meliputi gambar-gambar proyeksi seperti film bisu, film kartun dan sebagainya.

\section{METODE PENELITIAN}

Jenis penelitian yang dilakukan adalah penelitian tindakan kelas (classroom action recearch), yaitu penelitian reflektif oleh prilaku tindakan yang dilakukan oleh guru sendiri untuk memperbaiki proses pembelajaran yang menjadi tanggung jawabnya. Lokasi berlangsungnya penelitian di SMP Negeri 1 Sitiung. Pelaksanaan penelitian ini adalah peneliti sendiri yang merupakan guru mata pelajaran Bahasa Indonesia yang mengajar di SMP Negeri I Sitiung.

Subjek yang dimaksud tindakan dalam penelitian ini adalah peserta didik Kelas VIIF SMP Negeri 1 Sitiung yang berjumlah 30 orang. Mereka merupakan peserta didik kelas VIIF tahun pelajaran 2018/2019. Penelitian ini dilakukan 13 Februari sampai 30 April 2019. Penelitian terdiri dari dua siklus dengan masingmasing siklus terdiri dari 2 kali pertemuan.

Penelitian yang dilakukan adalah penelitian tindakan kelas yang terdiri dari empat rangkaian kegiatan yang dilakukan dalam siklus berulang seperti dirumuskan oleh Kemis dan Tanggart (Depdiknas, 2004:5) yaitu: perencanaan, pelaksanaan, tindakan dan observasi.

\section{HASIL PENELITIAN DAN PEMBAHASAN \\ Deskripsi Kondisi Awal}

Sesuai dengan hasil evaluasi yang dilaksanakan di awal (pre tes) ternyata hasil belajar yang didapat peserta didik rendah. Dari 30 orang peserta didik yang diamati, yang tuntas sebanyak 13 orang (43\%) sedangkan 17 orang lagi (56\%) tidak tuntas. Sedangkan nilai rata-rata yang didapat 68, dengan KKM bahasa Indonesia yang ditetapkan sebesar 70 .

Tabel 1. Rentangan ketuntasan hasil belajar bahasa Indonesia dalam aspek menelaah struktur dan kebahasaan surat pribadi dan surat dinas pada kondisi awal kelas VIIF SMPN I Sitiung

\begin{tabular}{|c|c|c|c|}
\hline NO & RENTANGAN NILAI & TUNTAS & TIDAK TUNTAS \\
\hline 1 & $\leq 49$ & & 1 \\
\hline 2 & $50-59$ & & 9 \\
\hline 3 & $60-69$ & & 7 \\
\hline 4 & $70-79$ & 2 & \\
\hline 5 & $80-89$ & 10 & \\
\hline
\end{tabular}




\begin{tabular}{|c|c|c|c|}
\hline 6 & $90-100$ & 1 & 17 \\
\hline \multicolumn{2}{|c|}{ Jumlah } & 13 & $56 \%$ \\
\hline & Persentase & $43 \%$ & \\
\hline
\end{tabular}

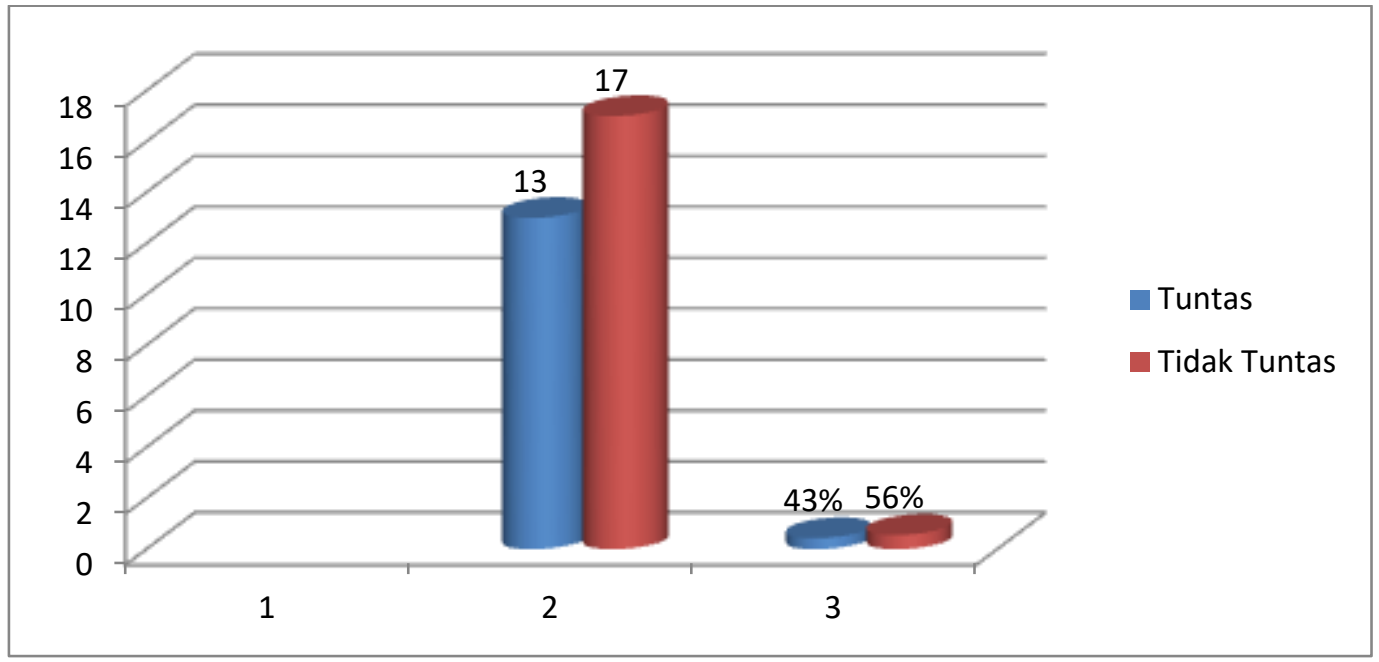

Gambar 1. Ketuntasan Hasil Belajar Bahasa Indonesia dalam aspek menelaah struktur dan kebahasaan surat pribadi dan surat dinas Siswa Kelas VII F SMPN I Sitiung pada Kondisi Awal

\section{Siklus I}

Penerapan media Pembelajaran rumah fantasi di Kelas VIIF SMP Negeri I Sitiung selama Siklus I dilaksanakan sebanyak dua kali pertemuan, yaitu pada tanggal 4 dan 5 Maret 2019 masing-masing selama 2 jam pelajaran (2x45 menit).

\section{Tahap Perencanaan}

Tahap perencanaan dimulai dengan persiapan materi pembelajaran bahasa Indonesia yang akan diterapkan dengan media pembelajaran rumah fantasi. Persiapan yang dilakukan meliputi: membuat Rencana Pelaksanaan Pembelajaran (RPP), menyusun bahan ajar dan soal-soal latihan untuk diberikan kepada peserta didik, menyiapkan teks fabel untuk media pembelajaran rumah fantasi yang akan digunakan selama siklus I, dan menyiapkan soal tes formatif yang akan diisi peserta didik pada akhir Siklus I.

\section{Tahap Pelaksanaan}

Pertemuan siklus I hanya dilakukan dua kali pertemuan, yaitu pada tanggal 4 dan 5 Maret 2019. Langkah selanjutnya adalah melaksanakan tindakan skenario pembelajaran sesuai dengan yang telah direncanakan bersama kolaborator untuk setiap siklus tindakan yang dilakukan mengikuti tahapan sebagai berikut yaitu kegiatan awal, kegiatan inti, dan kegiatan penutup.

\section{Data Hasil Belajar pada Penelitian Siklus I}

Penerapan Media Pembelajaran Rumah Fantasi pada peserta didik Kelas VIIF SMP Negeri I Sitiung telah memperlihatkan peningkatan hasil belajar yang cukup baik. Hal ini terlihat dari 5 butir soal uraian yang diberikan, hasilnya 14 
orang peserta didik yang mencapai KKM atau sekitar $47 \%$, dan yang tidak mencapai KKM mulai mengalami penurunan dari 17 orang pada prasiklus menjadi 16 orang $(53 \%)$ pada akhir siklus I. Secara klasikal rata-rata nilai hasil belajar pada akhir siklus I adalah 73 .

Tabel 2. Rentangan Hasil belajar Bahasa Indonesia dalam aspek menelaah struktur dan kebahasaan teks fantasi pada peserta didik kelas VIIF SMP Negeri I Sitiung dengan media pembelajaran rumah fantasi pada Akhir Siklus I

\begin{tabular}{|c|c|c|c|}
\hline NO & RENTANGAN NILAI & TUNTAS & TIDAK TUNTAS \\
\hline 1 & $\leq 49$ & & 3 \\
\hline 2 & $50-59$ & & 13 \\
\hline 3 & $60-69$ & & \\
\hline 4 & $70-79$ & & \\
\hline 5 & $80-89$ & 6 & 16 \\
\hline 6 & $90-100$ & 8 & $53 \%$ \\
\hline & Jumlah & 14 & \\
\hline & Persentase & $47 \%$ & \\
\hline
\end{tabular}

Pada tabel 2 di atas, menunjukkan hasil belajar peserta didik belum memenuhi standar ketuntasan belajar minimum 70. Nilai peserta didik sudah mulai mengalami peningkatan, sebagian besar berada pada kisaran 90--100 dengan jumlah peserta didik 8 orang dengan nilai rata-rata klasikal 73.

Apabila digambarkan dengan diagram Batang (Histogram) rentangan nilai dan persentase ketuntasan hasil belajar Bahasa Indonesia kelas VIIF SMPN I Sitiung melalui media pembelajaran rumah fantasipada akhir siklus I seperti dibawah ini:

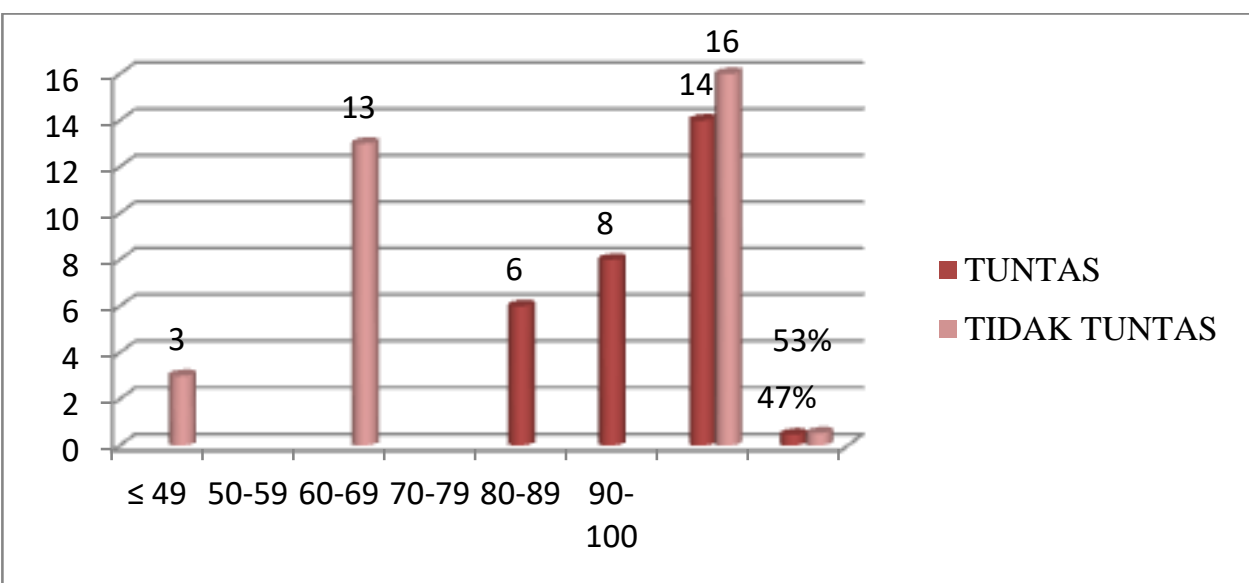

Gambar 2. Rentangan Nilai dan Persentase Ketuntasan Hasil Belajar Bahasa Indonesia dalam aspek menelaah struktur dan kebahasaan Siswa Kelas VII F SMPN I Sitiung Media Pembelajaran Rumah Fantasi pada Akhir Siklus I 


\section{Refleksi Siklus I}

Berdasarkan hasil pengamatan dari pelaksanaan pembelajaran ditemukan hal-hal seperti berikut. (1) Peserta didik kurang mempersiapkan diri belajar materi struktur dan kebahasaan teks dan malas membaca buku yang di instruksikan guru. Oleh karena itu, pengetahuan awal peserta didik tentang materi ini, masih kurang dan menemui kesulitan ketika menemukan sendiri struktur teks fabel. (2) Sebagian besar peserta didik benar dalam menemukan sendiri struktur teks fabel. Namun masih ada yang gagal. (3) Hanya 50 persen peserta didik yang dapat menemukan sendiri hal-hal yang menarik. (4) Sebagian besar peserta didik dapat menjawab soal tes formatif, tapi ada juga yang belum mampu menjawab dengan benar soal-soal tersebut.

\section{SIKLUS II}

Penerapan media pembelajaran rumah fantasi di Kelas VIIF SMP Negeri I Sitiung selama Siklus II dilaksanakan sebanyak dua kali pertemuan, yaitu pada tanggal 25 dan 26 Maret 2019 masing-masing selama 2 jam pelajaran (2x45 menit).

\section{Tahap Perencanaan}

Tahap perencanaan dimulai dengan persiapan materi pembelajaran bahasa Indonesia yang akan diterapkan dengan media pembelajaran rumah fantasi. Persiapan yang dilakukan meliputi membuat Rencana Pelaksanaan Pembelajaran (RPP) untuk siklus II variasi pengungkapan orientasi, menyusun bahan ajar dan soal-soal latihan untuk

diberikan kepada peserta didik, menyiapkan teks bacaan untuk media pembelajaran rumah fantasi yang akan digunakan selama siklus II, dan menyiapkan soal tes formatif yang akan diisi peserta didik pada akhir siklus II.

\section{Tahap Pelaksanaan}

Pertemuan siklus II dilakukan dua kali pertemuan, yaitu pada tanggal 25 dan 26 Maret 2019. Tahap pelaksanaan merupakan penerapan dari Rencana Pelaksanaan Pembelajaran (RPP) yang telah dirancang pada tahap persiapan. Adapun pelaksanaannya yakni kegiatan awal, kegiatan inti, dan kegiatan akhir. Pada pertemuan II dalam siklus II, guru melakukan hal yang serupa untuk indikator pencapaian selanjutnya, diakhir pembelajaran guru mengadakan tes formatif yang terdiri dari 5 butir soal uraian.

\section{Data Hasil Belajar Peserta didik Akhir Siklus II}

Berikut merupakan rentangan nilai dan ketuntasan hasil belajar bahasa Indonesia dalam aspek variasi pengungkapan orientasi peserta didik kelas VIIF SMP Negeri I Sitiung dengan menggunakan media Pembelajaran rumah fantasi pada akhir siklus II. 
Tabel 3. Rentangan Nilai dan Ketuntasan Hasil Belajar Siklus II

\begin{tabular}{|c|c|c|c|}
\hline NO & RENTANGAN NILAI & TUNTAS & TIDAK TUNTAS \\
\hline 1 & $\leq 49$ & & \\
\hline 2 & $50--59$ & & \\
\hline 3 & $60--69$ & & 2 \\
\hline 4 & $70--79$ & & \\
\hline 5 & $80--89$ & 17 & 2 \\
\hline 6 & $90--100$ & 11 & $0,06 \%$ \\
\hline \multicolumn{2}{|c|}{ Jumlah } & 28 & \\
\hline
\end{tabular}

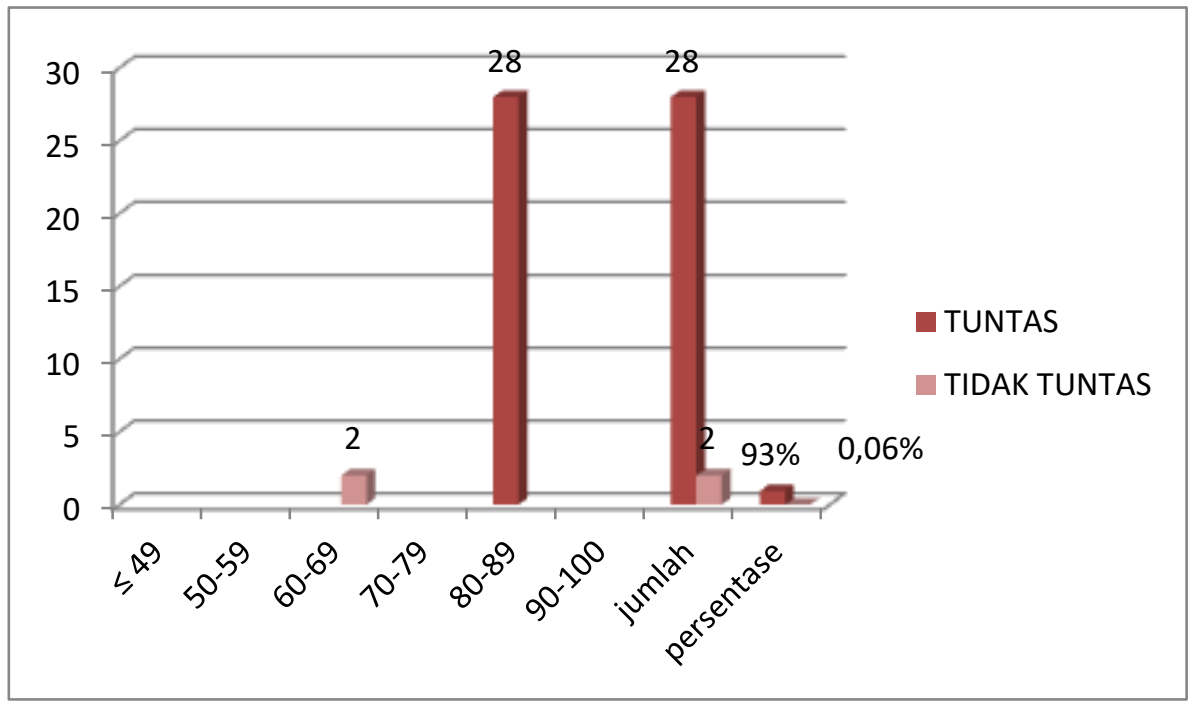

Gambar 3. Rentangan Nilai dan Persentase Ketuntasan Hasil Belajar

Bahasa Indonesia dalam Aspek variasi pengungkapan orientasi Siswa kelas VII F dengan Media pembelajaran rumah fantasi pada Akhir Siklus II

Data hasil belajar peserta didik pada akhir siklus II ini merupakan data pendukung pada penelitian tindakan kelas yang mengacu pada nilai tes formatif peserta didik. Nilai rata-rata ketuntasan klasikal bahasa Indonesia dengan penerapan media pembelajaran rumah fantasi menjadi sebesar 86. Peserta didik yang mencapai Kriteria Ketuntasan Minimal (KKM) sebesar 93\% atau sebanyak 28 orang, dan yang belum mencapai Kriteria Ketuntasan Minimal (KKM) mengalami penurunan menjadi $0,06 \%$ sebanyak 2 orang.

\section{Refleksi Siklus II}

Penerapan Media Pembelajaran rumah fantasi pada pembelajaran bahasa di Kelas VIIF SMP Negeri I Sitiung telah memperlihatkan peningkatan hasil belajar yang sangat baik. Peserta didik telah beradaptasi dengan media pembelajaran rumah fantasi yang dikembangkan. Pada saat penyajian materi awal oleh guru, 
seluruh peserta didik memperlihatkan antusias. Peserta didik telah mengetahui bahwa apabila memperhatikan pelajaran, mau membaca buku atau teks bacaan dengan sungguh-sungguh akan memudahkan menemukan. Hasil tes formatifnya pun menunjukan kemajuan.

Berdasarkan hasil pengamatan hasil belajar pada Siklus I dan II, peneliti melakukan refleksi dan membandingkan dengan indikator keberhasilan tindakan untuk penerapan media pembelajaran rumah fantasi pada mata pelajaran bahasa Indonesia di Kelas VIIF SMP Negeri I Sitiung, hasil belajar peserta didik telah mencapai hasil yang diharapkan, yaitu dengan nilai rata-rata ketuntasan klasikal 86 pada akhir siklus II.

Dengan demikian, berdasarkan data hasil belajar terlihat peningkatan sesuai Indikator yang diharapkan, maka siklus dalam penelitian ini tidak dilanjutkan.

\section{Pembahasan}

Dari hasil tes formatif yang telah dilakukan ternyata terjadi peningkatan hasil belajar Bahasa Indonesia melalui media pembelajaran rumah fantasi di kelas VIIF Tapel 2018/2019. Hal ini disebabkan karena peserta didik sudah memahami materi yang diajarkan dan peserta didik juga sudah memahami proses pembelajaran dengan menggunakan model inkuiri.

Persentase peningkatan ketuntasan hasil belajar peserta didik pada siklus I adalah $47 \%$ dan meningkat menjadi $93 \%$ pada siklus II. Dapat disimpulkan mengalami peningkatan sebanyak $46 \%$. Jumlah peserta didik yang nilainya di atas KKM pada siklus I berjumlah 16 orang meningkat menjadi 28 orang pada siklus II, yang berarti bertambah 12 orang.

Peningkatan nilai rata-rata klasikal bahasa Indonesia dalam aspek menelaah struktur dan kebahasaan dengan menggunakan media pembelajaran rumah fantasi pada peserta didik kelas VIIF SMP Negeri I Sitiung, dari $73 \%$ pada siklus I meningkat menjadi 93\% pada siklus II. Hal ini berarti peningkatannya sebesar 13 Poin dan mendapatkan respon yang positif dari peserta didik.

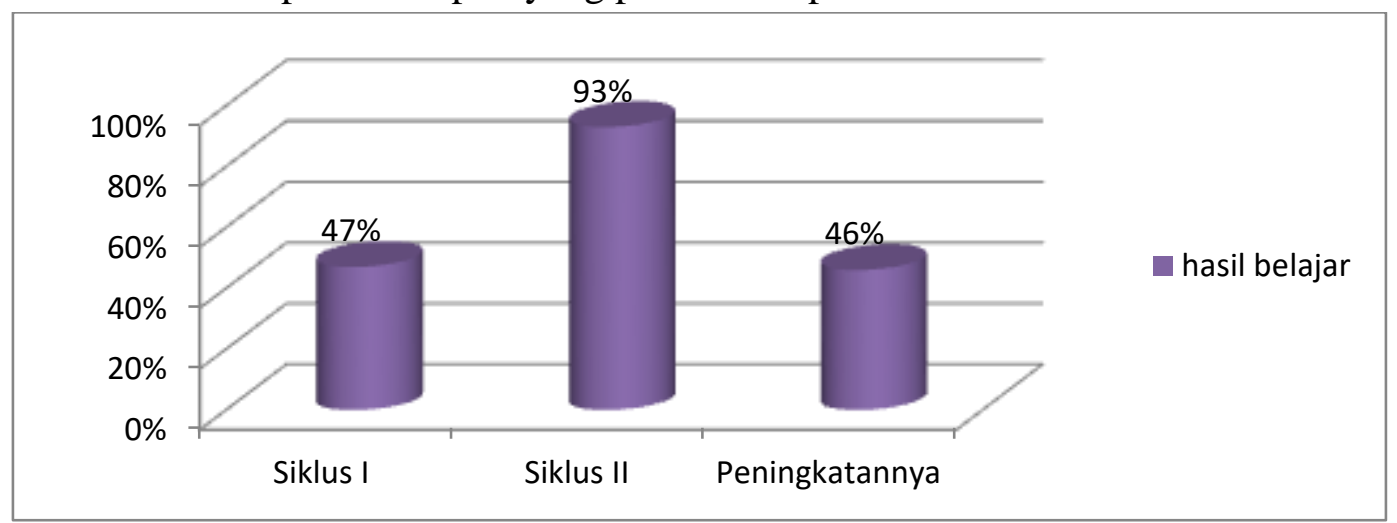

Gambar 4. Persentase Peningkatan Hasil Belajar Bahasa Indonesia dalam aspek menelaah struktur teks fabel Siswa kelas VII F SMPN I Sitiung melalui penerapan media pembelajaran rumah fantasi pada akhir siklus I dan akhir siklus II 


\section{KESIMPULAN DAN SARAN \\ Kesimpulan}

Berdasarkan temuan hasil penelitian, pada penelitian tindakan kelas dapat ditarik kesimpulan: "Jika pada peserta didik kelas VIIF Dharmasraya Tahun Pelajaran 2018/2019 dilakukan proses pembelajaran dengan menggunakan media pembelajaran rumah fantasi pada aspek menelaah struktur dan kebahasaan, maka akan terjadi peningkatan hasil belajar Bahasa Indonesia dari $43 \%$ pada kondisi awal meningkat $47 \%$ pada siklus I dan meningkat lagi menjadi $93 \%$ pada siklus II.

\section{Saran}

Dari hasil penelitian yang diperoleh dari uraian sebelumnya agar proses pembelajaran bahasa Indonesia lebih efektif dan lebih memberikan hasil yang optimal bagi peserta didik, maka disampaikan saran sebagai berikut. Menerapkan media pembelajaran rumah fantasi untuk meningkatkan hasil belajar pada mata pelajaran bahasa Indonesia dalam aspek menelaah struktur dan kebahasaan. Dalam penggunaan media pembelajaran rumah fantasi efesiensi waktu harus dirancang dengan baik. Bagi peserta didik yang terlibat dalam penelitian ini agar tetap menanamkan sikap positif dalam pembelajaran Bahasa Indonesia yaitu kreatif, inovatif, menjalin kerjasama yang baik, dan bersemangat dalam belajar. Bagi guru, dapat menggunakan model pembelajaran inkuiri pada materi lain pada mata pelajaran bahasa Indonesia dan mata pelajaran lain yang sesuai. Diharapkan rekan guru terus berupaya meningkatkan profesionalismenya dengan melahirkan inovasi dan kreasi berbagai model-model dan media pembelajaran pada mata pelajaran yang diampunya.

\section{DAFTAR PUSTAKA}

Arikunto.Suharsimi. 2007. Belajar Secara Efektif. Yogyakarta: Pustaka Insan Madani.

Aqib, Zainal. 2014. Model, Media, dan Strategi pembelajaran Kontekstual (Inovatif). Bandung: Yrama Widya

Azhar,Arsyad. 2011. Media Pembelajaran. Jakarta : Rajawali Pers

Basuki,Wibawa dan Farida Mukti. 2001. Media Pengajaran. Bandung : CV Maulana

Depdiknas. 2004. Kurikulum Pendidikan Dasar. Jakarta.

Dimyati dan Mujiono. 2006. Belajar dan Pembelajaran. Jakarta: Rineka Cipta

Djamarah, Syaiful Bahri. 2006. Strategi Belajar Mengajar: Jakarta: Rineka Cipta

Djamarah,,Syaiful Bahari, dan Aswan Zain. 2006. Strategi Belajar Mengajar. Jakarta: Rineka Cipta.

Rudi, S., \& Cepi, R. (2008). Media Pembelajaran. Bandung: Jurusan Kurtekpend FIP UPI.

Sudjana, Nana. (2004). Dasar-dasar Proses Belajar Mengajar. Bandung: Sinar Baru

Wibawa, Basuki dan Farida Mukti. (1992). Media Pengajaran. Jakarta: Dikti 